\title{
Overexpression of TP53 is Associated with Aggressive Prostate Cancer but does not Distinguish Disease in BRCA1 or BRCA2 Mutation Carriers from a Control Group
}

\author{
A. Mitra ${ }^{1}$, C. Jameson ${ }^{2}$, Y. Barbachano ${ }^{2}$, N. Sodha ${ }^{1}$, Z. Kote-Jarai ${ }^{1}$, A. Javed ${ }^{2}$, E. Bancroft ${ }^{2}$, \\ A. Fletcher ${ }^{1}$, Christopher S. Foster ${ }^{3}$, C. Cooper ${ }^{1}$, S. Peock ${ }^{4}$, D. Easton ${ }^{4}$ and R. Eeles ${ }^{1, *}$
}

${ }^{I}$ Cancer Genetics Unit, The Institute of Cancer Research, Surrey, UK; ${ }^{2}$ The Royal Marsden, NHS, Foundation Trust, London, UK; ${ }^{3}$ Division of Pathology, School of Cancer Studies, University of Liverpool, UK and ${ }^{4}$ Strangeways Research Laboratories, Cambridge, UK

\begin{abstract}
We have shown that prostate cancer occurring in men with germline BRCA1 and BRCA2 mutations is more aggressive. In an attempt to identify an associated immunohistochemical phenotype, we have studied TP53 immunostaining in prostate cancers in mutation carriers versus prostate cancers occurring in a control group of men.

There was a significantly higher expression of TP53 protein in prostate cancer with a higher Gleason score $(\mathrm{p}<0.001)$. Twenty four per cent of prostate cancer occurring in BRCA1/2 mutation carriers and $19 \%$ of those from controls stained positively for the TP53 protein; this difference was not significant.

Cases and controls were combined and matched for benign and malignant disease within the same individual. There were 152 men who had a sample of each within the tissue samples. Thirty one (20\%) stained positively within the malignant tissue alone; none had positive staining in benign tissue, $\mathrm{p}<0.001$.

Over expression of TP53 cannot distinguish prostate cancer on a background of BRCA1/2 mutation, but it is associated with prostate cancer malignant tissue per se, in particular aggressive disease.
\end{abstract}

\section{INTRODUCTION}

Prostate cancer $(\mathrm{PrCa})$ is one of the most common male cancers in the UK. It has a wide spectrum of aggressiveness and so its management is controversial. Men who carry a mutation in the BRCA2 gene and to a lesser extent BRCA1 gene have an increased relative risk of $\mathrm{PrCa}$, particularly of disease which occurs at a younger age of onset $(<65$ years). This relative risk may be as high as 7-23 times the general population risk in $B R C A 2$ mutation carriers and 1.8 times in $B R C A 1$ mutation carriers by 65 years [1,2]. In addition, men who are carriers of $B R C A 2$ mutations have a significantly higher Gleason score, lower mean age of diagnosis, more advanced stage and shorter median survival when compared with a control group $[3,4]$. Identifying those who harbour a $B R C A 1$ or $B R C A 2$ gene mutation would enable us to easily highlight a group of men who are more likely to develop $\mathrm{PrCa}$ that has an aggressive natural history. It would also enable the identification of their families as being at increased risk of other $B R C A 1 / 2$ gene mutation associated cancers.

Genetic testing for $B R C A 1$ and $B R C A 2$ germ line mutations is expensive and time consuming because of the large size of both the genes and the low percentage of mutations in the population. Finding pathological features characteristic of PrCa specifically from $B R C A 1 / 2$ mutation carriers would be of value in targeting genetic testing.

*Address correspondence to this author at the Institute of Cancer Research, 15, Cotswold Road, Belmont, Sutton, Surrey, SM2 5NG, UK;

E-mail: Rosalind.Eeles@icr.ac.uk
Levels of TP53 protein detected by immuno-histochemistry are increased in BRCAl gene mutation carriers with breast cancer compared with sporadic disease. This difference remains when the mutation carriers and sporadic breast cancers are matched for grade [5, 6].

TP53 protein is one of the major regulators of the cell cycle preventing inappropriate cell proliferation and ensuring maintenance of the genome following cellular stress. Malignant tumours developing in BRCAl mutation carriers have increased levels of TP53 protein as detected by immunohistochemistry. BRCA1 and BRCA2 proteins interact with RAD51 protein, which is involved in the recombination and repair of DNA double stranded breaks [7,8]. A cell that lacks functional BRCA1 or 2 proteins may have a decreased ability to repair DNA damage resulting in increased genomic instability and ultimately leading to TP53 mediated cell cycle arrest and/or apoptosis. In support of this hypothesis, researchers have observed that brcal gene deficient mice die early in embryogenesis, exhibiting reduced cellular proliferation and increased expression of the $p 21$ tumour suppressor gene $[9,10]$. In addition, brcal deficient mice can be partially rescued from early embryonic lethality by the presence of $p 53$ or $p 21$ null mutations [10].This finding suggests that loss of $p 53$ checkpoint control may be obligatory for the malignant transformation in cells with a brcal/2 gene mutation and that it must occur prior to the 'second hit' in the brcal gene, in order for the brcal -/- (null) cells to overcome cell cycle arrest. In this case, the $p 53$ gene would be mutated producing an abnormal protein. Loss of $\mathrm{p} 53$ checkpoint control in such a clonal population would enable the accumula- 
tion of the further somatic genetic abnormalities necessary for tumourigenesis.

Mutant p53 protein is resistant to degradation and therefore has a prolonged half life allowing it to be detected by immuno-histochemical staining. Carcinomas in patients who carry $B R C A 1$ gene mutations might therefore be expected to exhibit a high rate of somatic TP53 gene mutations. This may also be expected in the development of $\mathrm{PrCa}$ in $B R C A 1 / 2$ gene mutation carriers. Indeed, TP53 gene mutations have been sequenced in BRCAl gene mutation carriers with breast cancer $[5,11]$.

Protein levels of TP53 in sporadic prostate cancer have been studied by several groups in a variety of specimen types (primary tumours and metastases). These studies have revealed a relationship between raised TP53 protein levels and high tumour grade [12-17] and advanced stage [13, 14, 18, 19]. They suggest that TP53 protein expression is associated with poorer prognosis $\mathrm{PrCa}$ and in some cases is an independently poor prognostic factor [20]. There are no data in the literature however regarding TP53 protein levels in BRCA1/2 gene mutation carriers with PrCa. This paper presents findings on immunohistochemical staining for TP53 protein in prostate tumours from $B R C A 2 / 1$ mutation carriers.

\section{MATERIALS AND METHODS}

\section{Study Patients}

Prostate tumour tissue was collected from men prior to treatment with germline mutations in $B R C A 1$ or $B R C A 2$ and a control group. The controls had a low probability of BRCA1/2 mutation. The samples were collected from throughout the UK. These tissues were immunohistochemically stained for TP53 protein.

The PrCa cases from men with germline BRCAl or $B R C A 2$ mutations were identified from four sources described below:

\section{The EMBRACE Study}

Men with PrCa enrolled in the Epidemiological Study of Familial Breast Cancer (EMBRACE www.srl.cam.ac.uk/ genepi/embrace/embrace)) had consented to the use of their prostate tissue samples for further research. The hospitals where these men had undergone prostate biopsy, prostatectomy or transurethral resection of the prostate (TURP) sent blocks/slides containing prostate tissue to AM. This material was coded anonymously with a unique study number. Where original haemotoxylin and eosin slides were not sent, new ones were cut at The Institute of Cancer Research from the blocks provided. Twelve cases were obtained in this manner from England, Ireland and Scotland.

\section{The IMPACT Study}

IMPACT, Identification of Men with a Genetic Predisposition to Prostate Cancer: Targeted Screening in BRCA1/ 2 Mutation Carriers and Controls (www.impact-study.co.uk) is an international PrCa screening study for men unaffected by cancer with a known $B R C A 1$ or $B R C A 2$ mutation. One man who was diagnosed with $\mathrm{PrCa}$ was recruited from the IMPACT study.

\section{A Cancer Genetics Out Patient Clinic}

One individual was recruited from the Cancer Genetics outpatient clinic in the Royal Marsden Hospital NHS Foundation Trust (RMH) via the UK Genetic Prostate Cancer Study (UKGPS http://www.icr.ac.uk/research/research_ sections/cancer_genetics/uk_prostate_study_group).

\section{A series of Young Onset PrCas from the Institute of Cancer Research}

A mixture of prostatectomies, trans-urethral resection of prostates (TURPs) and prostate biopsies mounted individually on slides were used. A series of 263 men who had prostate cancer diagnosed under the age of 55 years had previously undergone retrospective $B R C A 2$ mutation analysis using conformational sensitive capillary electrophoresis (CSCE), which was then confirmed on sequencing. Prostate tissues from the six men found to have deleterious BRCA2 mutations were incorporated into the current study [2].

The clinical features are outlined in Table $\mathbf{1 .}$

Controls were obtained from 2 sources. 52 cases were obtained from prostate tissue micro-arrays (TMAs) formed from transurethral resection of the prostate (TURPs) and prostatectomy samples from men with young onset $\mathrm{PrCa}$ diagnosed between the ages of 38-55 years with a median of 51 years, diagnosed between 1990 and 1998. The PSA ranged from $0.9-1422 \mathrm{ng} / \mathrm{ml}$, TNM stage from T1a to T4 (2002 classification). The majority of men presented with symptomatic disease. These men were diagnosed with $\mathrm{PrCa}$ from throughout the UK between the years of 1990-1998. The method of the creation of this series of patients is described elsewhere [21]. A further ninety one controls were obtained from TMAs from TURP and prostatectomy samples from men who had developed PrCa within England and were treated at the Royal Marsden NHS Foundation Trust $(\mathrm{RMH})$ from 1992. Their ages ranged from 43-85 years with a median of 67 years. Written consent was obtained from the control patients via the UK Genetic Prostate Cancer Study (UKGPCS) study currently being conducted at the ICR/ $\mathrm{RMH}$.

\section{Immunohistochemical Analysis for TP53}

The antibody conditions were optimised by choosing a control of colonic tissue which stains well for TP53. The temperature, $\mathrm{pH}$ and dilution had been adjusted at the Royal Marsden NHS Foundation Trust histopathology laboratories.

Immunohistochemical staining for TP53 was performed by the Ventana Benchmark XT ${ }^{\mathrm{TM}}$ immunohistochemistry platform which uses a labelled streptavidin-biotin system. Paraffin was removed by heating, adding detergent and vortex mixing. Antigen retrieval was achieved by the addition of $\mathrm{CC} 1$, a tris based buffer added at $95^{\circ} \mathrm{C}$, for 60 minutes. The primary antibody was a rabbit anti-p53 purified polyclonal antibody (Novocastra ${ }^{\mathrm{TM}}$ ) added at room temperature over a 40 minute period. The dilution was 1 in 50 . The secondary antibody (anti-mouse antibody), labelled with biotin was added at room temperature over a 25 minute period. The streptavidin-peroxidase complex was added at room temperature over 25 minutes. Diaminobenzidine (DAB) was added at room temperature and a haematoxylin counter-stain 
Table 1. Clinical Characteristics and TP53 Staining of the Mutation Carriers and Controls

\begin{tabular}{|c|c|c|c|}
\hline Number analysed & 17 & \multicolumn{2}{|c|}{135 in total } \\
\hline Median age & 53 & 51 & 67 \\
\hline PSA (ng/ml) & $<1.0-227$ & $0.9-1422.0$ & Unknown \\
\hline Stage (AJCC 2002) & T1a-T4 - M1 & T1a-T4-M1 & T1a-T4-M1 \\
\hline TP53 \% staining (PCI) & $0-75 \%$ & $0-80 \%$ & $0-95 \%$ \\
\hline Mutations & $\begin{array}{c}\text { BRCA1 } \\
\text { c.68_69delAG }(\mathrm{n}=2) \\
\text { c.3756_3759delGTCT } \\
\text { c.1175_1214del40 } \\
\text { BRCA2 } \\
\text { c.5946delT } \\
\text { c.5682C>G } \\
\text { c.7543dupA } \\
\text { c.6275_6276delTT }(\mathrm{n}=2) \\
\text { c.3158T }>\mathrm{G}(\mathrm{n}=2) \\
\text { c.2330dupA } \\
\text { c.7545dupA } \\
\text { c.7977-1G>C } \\
\text { c.5303_5304delTT } \\
\text { c.8167G }>\mathrm{C} \\
\text { c.8297delC }\end{array}$ & & \\
\hline
\end{tabular}

was added before the slide was dehydrated in alcohol and cleaned in xylene.

\section{Morphological Studies and Immuno-Histochemical Staining}

The histopathology slides were cut at a thickness of 3-4 microns. Two weeks elapsed between cutting the sections of the paraffin blocks and staining them for the TP53 protein. A single histopathologist (Charles Jameson) and AM reviewed all the tissue microarray (TMA) controls and case samples. Each TMA and each conventionally prepared case was stained with TP53 and a haemotoxylin and eosin (H and E) stain. The $\mathrm{H}$ and $\mathrm{E}$ stain was taken to give an accurate representation of the Gleason score at the layer as close as possible to the section where the tissue was stained with TP53 antibody.

Each case was scored for Gleason pattern and the percentage of the tumour cells and benign cells that had stained for the TP53 antibody. Note was made of whether the nucleus or cytoplasm had stained in each specimen. For each individual there was more than one section of tumour and benign tissue. Where there was a discrepancy in Gleason score, the highest grade was taken as is undertaken in the clinical setting when diagnosing individual cases of PrCa. In cases where there was a discrepancy in the percentage of cells stained (tumour or benign tissue), an average was taken. The immuno-histochemical staining was analysed using the concept of Positive Cell Index (PCI), the proportion of positively stained tumour cells [22]. The PCI ranged from $0-95 \%$. A sample was classified as positive for TP53 immuno-staining if more than $20 \%$ of the cells were stained. Figs. (1 and 2) show examples of TP53 protein staining in prostate tissue samples used in this study.

\section{Statistical Analysis}

Fisher's exact test was used to compare the proportion of subjects staining positive in the carrier and control groups. The proportions with positive staining in the low/intermediate Gleason score $(\leq 7)$ and high Gleason score $(>7)$ groups were compared in the same way. To test whether there was a difference in staining between the benign and malignant tissue of the same patient a sign test was used. Differences were considered significant if the p-value was $<0.05$.

\section{RESULTS}

When the histopathology of each malignancy was reviewed, 3 of the cases of BRCA2 mutation carrier specimens were insufficient to provide reliable data and were omitted from the analysis. Of the controls, 135 of the 143 samples provided sufficient material for analysis.

There was a significantly higher expression of TP53 protein in $\mathrm{PrCa}$ with a higher Gleason score i.e. more poorly differentiated disease ( $\mathrm{p}<0.001$, Fisher's exact test). This was seen in the combined cases and controls (Table 2) and 


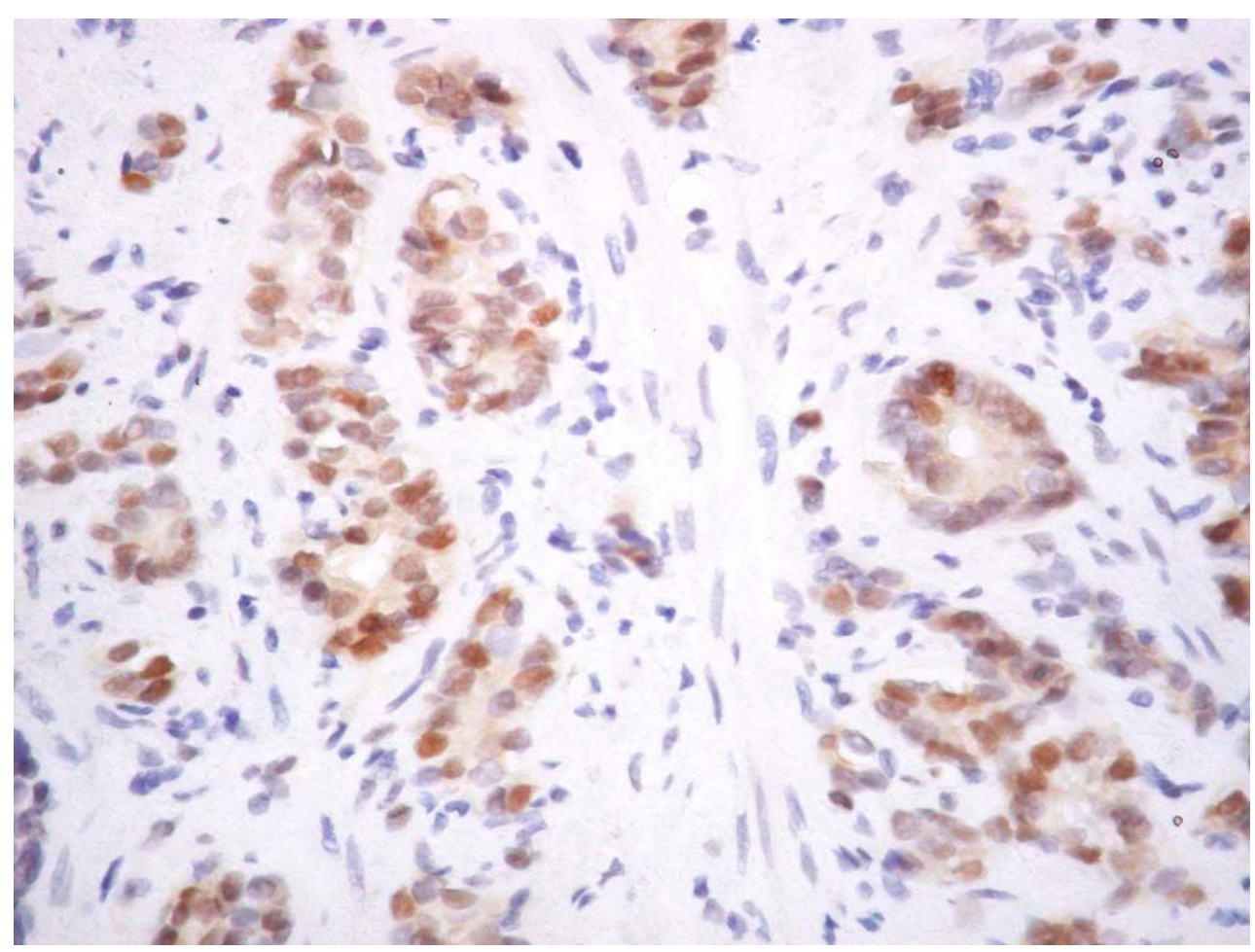

Fig. (1). PrCa Gleason $3+5$ tissue in a BRCA1 mutation carrier; $75 \%$ of the nuclei stain with TP53 antibody.

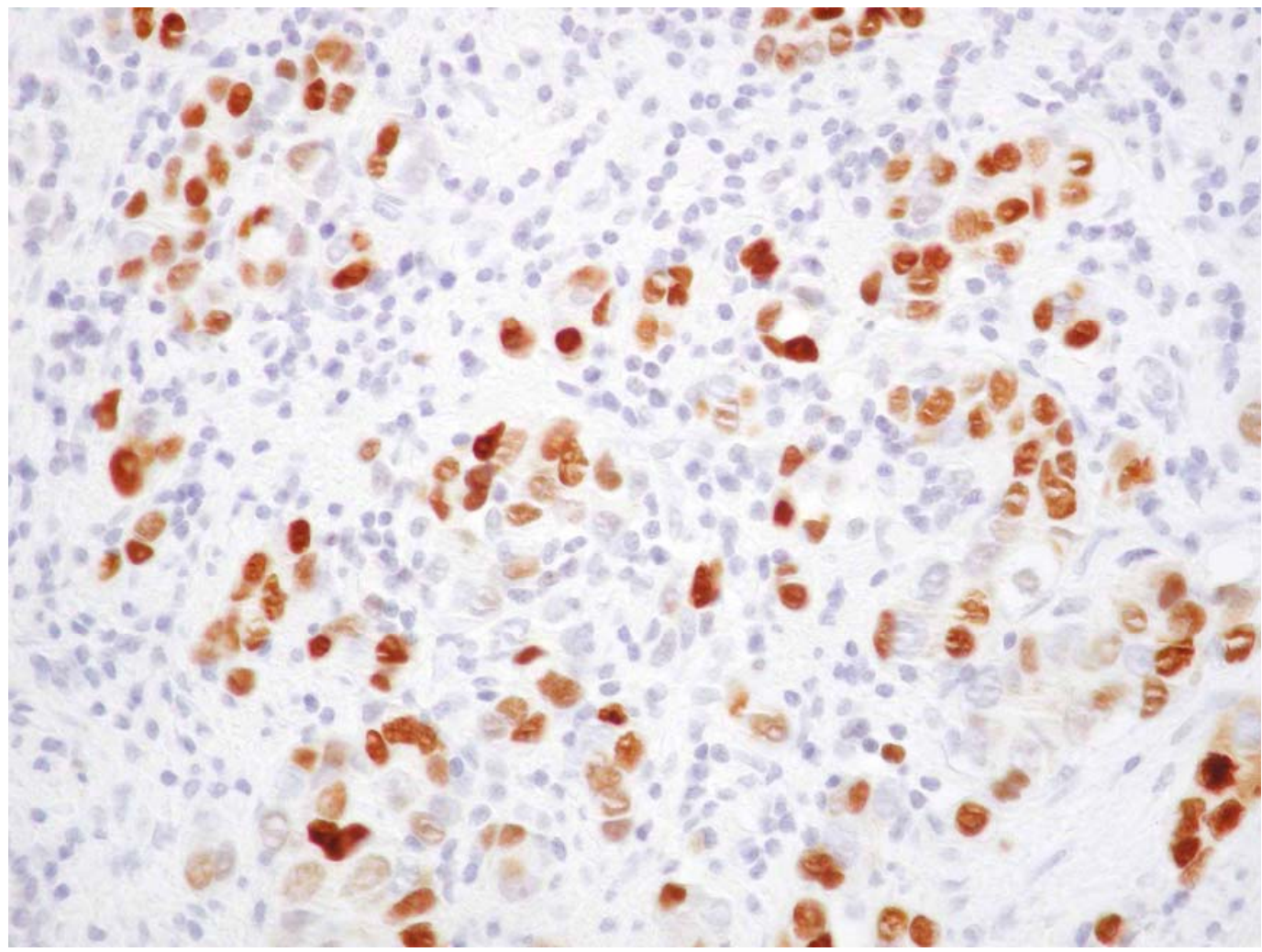

Fig. (2). PrCa Gleason $4+4$ tissue in a BRCA2 mutation carrier; 33\% of the nuclei stain with TP53.

also in the controls alone. There was a highly significant difference between TP53 protein staining seen in malignant and benign tissue. None of the benign tissue but $20 \%$ of the malignant tissue stained for TP53 ( $\mathrm{p}<0.001$ sign test). There was no significant difference between the TP53 protein staining seen in BRCA1/2 mutation carriers and controls (Table 2). 
Table 2. Positive Staining (Defined as $>20 \%$ PCI) for TP53 Protein in Mutation Carriers and Controls

\begin{tabular}{|c|c|c|c|}
\hline $\begin{array}{c}\text { Comparison } \\
\text { Groups }\end{array}$ & Subjects & $\begin{array}{c}\text { TP53 Positive Staining Result } \\
\text { Numbers (\%) }\end{array}$ & $\begin{array}{c}\text { p-Value } \\
\text { Fisher's Exact Test }\end{array}$ \\
\hline \hline \multirow{2}{*}{ Mutation carriers vs controls } & $\begin{array}{c}\text { BRCAl/2 } \\
\text { mutation carriers }\end{array}$ & $4 / 17(23.5 \%)$ & $\mathrm{p}=0.52$ \\
\cline { 2 - 4 } Combined cases and controls & Controls & $24 / 135(18.5 \%)$ & $\mathrm{p}<0.001$ \\
\cline { 2 - 4 } & Gleason $>7$ & $21 / 64(32.8 \%)$ & $7 / 88(7.9 \%)$ \\
\hline
\end{tabular}

The Gleason pattern ranged from $3+3$ to $5+5$. All tumours were prostate adenocarcinomas. The PCI within the nuclei of the PrCas ranged from 0 to $75 \%$. The cytoplasm did not stain in any of the cases. Table 1 summarises the mutation carriers' characteristics.

The Gleason scores in the young onset PrCa controls ranged from $3+3$ to $5+5$. Twelve of these controls stained within the nucleus of the tumour, percentage staining ranging from 0 to $80 \%$ of the cancerous cells. None of the benign tissues stained either in the cytoplasm or the nucleus. In the 91 cases of $\mathrm{PrCa}$ of onset in all age ranges, the Gleason scores ranged from $3+3$ to $5+5$. The percentage of tumour cells that stained only the nucleus (no cytoplasmic staining was seen) ranged from 0 to $95 \%$. Twenty three cases of the 91 stained for TP53 protein.

\section{DISCUSSION}

This is the first UK series of PrCa from BRCA1/2 gene mutation carriers that has been stained for TP53 protein. These PrCas did not express significantly higher levels of nuclear TP53 protein compared with the PrCas in the control group. TP53 immuno-staining was seen in cases and controls in the nuclei of the cancerous cells but none were seen in the cytoplasm or within benign tissue. As TP53 is present in the nucleus this confirms that the optimisation and immunohistochemical technique was appropriate.

Immuno-histochemical staining of TP53 protein was in accordance with other reports in the literature in PrCa. The presence of positive staining for TP53 protein has been found to vary between tumours and is found in $18-25 \%$ of sporadic PrCas [17, 23, 24]. In the study reported here, twenty four per cent of the PrCa cases who were carriers of BRCA1/2 gene mutations and $18.5 \%$ of the PrCa controls (non-mutation carriers) stained for a level of TP53 above the threshold of $20 \%$. Twenty nine per cent $(5 / 17)$ of the BRCA1/2 mutation carrier PrCa cases and 25\% (34/135) of the controls stained for TP53 at a level greater than $5 \%$ of the cancerous cells stained. This was not a significant difference $(p=0.770)$. The latter data are not shown.

Other groups have found correlations between levels of TP53 and prognosis and grade of PrCa. TP53 protein expression in sporadic PrCa has been shown to be associated with high grade or advanced stage disease, time to disease progression, survival and relapse although the results are sometimes equivocal $[17,25,26]$. Despite these findings, compared with other cancers, the overall prevalence of TP53 protein in PrCa is relatively low. Rodrigues et al. observed immuno-histochemically detectable TP53 levels in 50\% of colorectal cancers [27]. In breast cancer, the accumulation of TP53 protein has been detected in about $20 \%-50 \%$ of tumours [28]. Lakhani et al. (2002) have shown that breast cancer in BRCA1 mutation carriers was significantly more likely to be positive for TP53 immuno-histochemical staining [6]. There is a lower rate of allelic loss at or near the TP53 locus in PrCa compared with colorectal and breast cancer suggesting that loss of TP53 function is not common in $\mathrm{PrCa}$ [29].

Although there was a significantly higher level of TP53 protein in all PrCas with a combined Gleason score > 7 (Gleason 8-10), no difference in TP53 protein expression was seen in the series of $B R C A 1 / 2$ gene mutation carriers when compared with non-mutation carriers with PrCa.

The analysis was repeated comparing Gleason score $>6$ with Gleason score $\leq 6$ and a statistical difference was still detected, $\mathrm{p}<0.001$ Fisher's test.

Analysis of immuno-histochemical data in this series was repeated for 5\% as the cut-off point for TP53 positivity varies between studies. Visakorpi et al. (1992) showed that intense staining with TP53 as defined by a cut-off value of $20 \%$ was associated with poorly differentiated PrCa, DNA aneuploidy and high cell proliferation rate [12]. A level of TP53 protein expression less than $20 \%$ did not show any prognostic significance in any situation. Shurbaji et al. (1995) also found TP53 expression was an independent prognostic indicator for time to progression for PrCa but any degree of immuno-reactivity was prognostically significant, in contrast to the $20 \%$ cut-off used by the Visakorpi paper [17]. The variations in TP53 positivity between papers make them difficult to compare. A cut-off of $20 \%$ to define 'highintensity' TP53 expression was used in this study. When Visakorpi (1992) used this level it was significantly associated with a poor outcome and this has been confirmed in other studies investigating PrCa and in other organ systems [26, 30]. Grignon et al. (1997) point out that studies' of breast cancer and PrCa from their laboratories show that a $20 \%$ level of TP53 expression correlates with the presence of a mutation in more than $90 \%$ of cases $[31,32]$. There was still no difference in this study between the $B R C A 1 / 2$ cases and controls in TP53 expression at the threshold of $5 \%$.

The BRCA1/2 mutation carriers were genotyped in this study, but not the sporadic patient cases. The number of controls was large enough to justify not testing the mutation 
status in all of them. BRCA1 and BRCA2 mutation carriers are not common in the UK, occurring in $0.12 \%$ and $0.20 \%$ of the population respectively [33]. The chance that a $B R C A 1 / 2$ mutation carrier would contaminate the control group is therefore very low.

The small numbers of cases limit the power of this study. The comparison of whole tissue sections in the cases compared with TMAs in the control group is also a limitation. The uptake of the TP53 protein can be patchy and comparing differently cut sections may introduce bias in the staining of the tissue. However, further investigation of TP53 immunostaining of $\mathrm{PrCa}$ in $B R C A 1$ and $B R C A 2$ gene mutation carriers is warranted.

\section{CONCLUSION}

This is the first time immuno-histochemical staining for TP53 protein has been undertaken in a series of $B R C A 1 / 2$ mutation carriers with PrCa.. This series is strengthened by the fact that the mutation carriers are a heterogeneous group and do not consist of only founder mutations and this group of men is therefore representative of the mutation carriers within the population of the UK. Unlike BRCAl gene mutation carriers with breast cancer, there is not an increased TP53 expression in PrCa tissue from BRCA1/2 mutation carriers so although TP53 has been associated with a higher Gleason score, our results indicate that this protein is not a useful immuno-histochemical marker in distinguishing $\mathrm{PrCa}$ in BRCA1/2 mutation carriers from non carriers in the UK population.

\section{ACKNOWLEDGEMENTS}

This study was funded by The Ronald and Rita McAulay Foundation with thanks to Dr. Ana Díez and the staff at the Centro Nacional de Investigaciones Oncologicas, Madrid, Spain and to the patients who donated samples. The study is also supported by Cancer Research UK as is the EMBRACE study. The Biomedical Research Centre provides NIHR Funding to The Institute of Cancer Research and The Royal Marsden NHS Foundation Trust.

\section{ABBREVIATIONS \\ $\mathrm{PrCa}=$ Prostate cancer \\ $\mathrm{RMH}=$ Royal Marsden NHS Foundation Trust \\ ICR = Institute of Cancer Research}

\section{THE IMPACT STEERING COMMITTEE}

Dr Rosalind Eeles;_Dr Zsofia Kote-Jarai; Dr Jane Melia; Dr Anita Mitra, Ms Clare Moynihan, (Institute of Cancer Research, London, UK); Mrs Audrey Ardern-Jones, Miss Elizabeth Bancroft, Dr Yolanda Barbachano, Professor David Dearnaley; Dr Vincent Khoo; (Royal Marsden NHS Foundation Trust, London, UK); Professor Doug Easton, Dr Susan Peock (Strangeways Research Laboratories, Cambridge, UK); Professor Chris Bangma, Professor Fritz $\mathrm{H}$ Schröder (Erasmus University Medical Center, Rotterdam, The Netherlands); Professor Diana Eccles (Wessex Clinical Genetics Service, Southampton, UK); Professor Gareth Evans (St Mary's Hospital, Manchester, UK); Professor Jorunn Eyfjord (Icelandic Cancer Society, Reykjavik, Ice- land); Dr Alison Falconer (Charing Cross Hospital, London, UK); Professor Christopher Foster (Royal Liverpool University Hospital, Liverpool, UK); Professor Henrik Grönberg (University Hospital, Umea, Sweden); Professor Freddie Hamdy (Royal Hallamshire Hospital, Sheffield, UK); Dr Óskar Pór Jóhannsson (University Hospital of Iceland, Reykjavik, Iceland); Professor Hans Lilja (Memorial SloanKettering Cancer Center, New York, USA); Professor Jan Lubinski (International Hereditary Cancer Centre, Szczecin, Poland); Dr Lovise Maehle (Norwegian Radium Hospital, Oslo, Norway); Dr Gillian Mitchell Peter MacCallum Cancer Institute, Melbourne, Australia); Dr Gad Rennert (Carmel Medical Center, Haifa, Israel); Dr Mohnish Suri (Nottingham City Hospital, Nottingham, UK); Dr Paul Sibley (Siemens, Gwynedd, UK); Dr Penny Wilson (Independent Advisor, Manchester, UK), Mr. AM (Patient Representative).

\section{THE IMPACT COLLABORATING CENTRES}

AUSTRALIA: Peter MacCallum Cancer Institute, Victoria (Dr Gillian Mitchell, Mary-Anne Young, Rebecca Doherty, Sarah Pratt); The Queensland Institute of Medical Research, Brisbane (Dr Georgia Chenevix-Trench); Royal Melbourne Hospital, Melbourne (Dr Geoffrey Lindeman), South Australia Clinical Genetics Service, North Adelaide (Dr Graeme Suthers, Ms Meryl Altree); Repatriation General Hospital, Adelaide (Dr Alan Stapleton, Dr Louise Taylor); AUSTRIA: University Hospital of Innsbruck (Professor Georg Bartsch); Universitat fur Frauenheilkunde, Vienna (Professor Teresa Wagner, Ms Christine Furhauser, Prof.Dr.Christian Singer, Dr Verena Korn); BULGARIA Medical University of Sofia, Sofia (Dr Radka Kaneva, Dr Atanaska Mitkova; Assistant Professor Chavdar Slavov, Dr Elenko Popov); St. Marina University Hospital, Varna (Prof Alexander Hinev); National Human Genome Center, Sofia (Prof. Draga Ivanova Toncheva, Prof. Stoyan Ganchev, Dr Ivanka Dimova); CYPRUS: The Cyprus Institute of Neurology \& Genetics, Nicosia (Dr Kyriakos Kyriakou; Andreas Hadjisavvas); DENMARK, Vejle Hospital, Veijle (Dr Dorthe Cruger); Fredericia and Kolding Hospital, Fredericia (Professor Palle Osther); Odense University Hospital, Odense (Dr Anne-Marie Gerdes); ESTONIA: Tartu University Hospital, Tartu (Dr Hele Everaus); FRANCE: Laboratoire D'Oncologie Moléculaire, Clermont-Ferrand (Professor Yves-Jean Bignon); GERMANY: Universitäts-Frauenklinik zu Köln, Köln (Prof. Dr. Rita Schmutzler, Dr Kerstin, Luedtke-Heckenkamp); German Cancer Research Center, Heidelberg (Dr Jenny Chang-Claude); GREECE, IRRP, National Centre for Scientific Research, Athens (Dr Drakoulis Yannoukakos, Dr Theodore Anagnostopoulos); HUNGARY: National Institute of Oncology Budapest (Prof E Olah); ICELAND: University Hospital of Iceland, Reykjavik (Dr Óskar Pór Jóhannsson); INDIA, Cancer Institute (WIA), Adyar Chennai (Dr T Rajkumar); ISRAEL: Hadassah University Medical Center, Jerusalem (Dr Asher Salmon), Chaim Shema Medical Center, Tel-Hashomer (Dr Eitan Friedman); ITALY: Instituto Nazionale Tumori, Milano (Dr P Radice / Dr N Nicolai / Riccardo Valdagni), University of Pisa, Pisa (Dr Maria Caligo, Prof Generoso Bevilacqua); LATVIA: Riga Stradins University (Dr Andris Abele, Riga Prof Janis Gardovskis, Dr Arvids Irmejs), MONGOLIA: Mongolian Development Institute, Ulaanbaatar (Dr M.Nansalmaa); NORWAY: Norwegian Radium, Oslo (Dr 
Lovise Maehle, Dr Pal Moller, Dr Bjorn Brennhovd); POLAND: International Heredetiary Cancer Centre, Szczecin (Dr Cezary Cybulski); ROMANIA: University of Medicine and Pharmacy Craiova, Craiova (Prof F Mixich, Dr VA Mixich); Sf Ioan Hospital Bucharest, Bucharest (Prof E Ionica, Prof M Costache, Dr A Mihalcea, Dr V Tica, Dr C Vrabie, Prof P Geavlete, Dr D Georgescu); RUSSIA: Russian Academy of Medical Sciences, Moscow (Dr Ludmila Lyubchenko); SLOVAKIA: National Cancer Institute, Bratislava (Dr Denisa Ilencikova, Dr Lucia Copakova); SLOVENIA: Institute of Oncology Ljubljana, Ljubljana (Dr Janez Zgajnar, Mateja Krajc); SPAIN: Catalonian Institute of Oncology, Barcelona (Dr Ignacio Blanco, Dr Merce Peris); Centro Nacional Investigaciones Oncologicas, Madrid (Prof Javier Benitez, Dr Ana Osorio); Hospital Clinico San Carlos, Madrid (Dr Pedro Perez Segura, Dr Trinidad Caldes); SWEDEN: The Jubileum Institute, Lund (Professor Hakan Olsson, Dr Niklas Loman); University Hospital of Lund, Lund (Professor Ola Bratt); Karolinska Institute, Stockholm (Dr Brita Arver); THE NETHERLANDS: Leiden University Medical Centre, Leiden, (Dr C.J. van Asperen), University Medical Centre Nijmegen, Nijmegen (Professor Bart Kiemeny, Dr Hans Vasen); The Netherlands Cancer Institute, Amsterdam (Dr Matti Rookus, Dr Fernando van Leeuwen, Dr Richard Brohet); TURKEY: Akdeniz University, Antalya (Prof G Luleci, Dr Esra Manguolu); Institute for Experimental Medical Research (DETAE), Istanbul (Dr Ugur Ozbek); UNITED KINGDOM: Royal Marsden NHS Foundation Trust (Dr Alan Thompson, Prof Cyril Fisher and Dr Charles Jameson); Institute Of Cancer Research, Surrey (Professor Colin Cooper): South East Thames Regional Genetics Service, Guys Hospital, London (Dr Louise Izatt; Dr Gabriella Pichert, Chris Jacobs; Caroline Langman); North of Scotland Regional Genetics Service, Aberdeen (Dr Helen Gregory, Prof Neva Haites); North West Thames Regional Genetics Service, Harrow (Dr Huw Dorkins, Carole Cummings), East Anglian Regional Genetics Service, Cambridge (Dr Joan Paterson, Dr Virginia Clowes, Barbara Newcombe); Peninsula Clinical Genetics Service, Exeter (Dr Carole Brewer, Anne Searle); Manchester Regional Genetics Service, Manchester (Prof Gareth Evans, Barbara Bulman); Nottingham Genetics Centre, Nottingham (Dr Mohnish Suri); Oxford Regional Genetics Service, Oxford (Dr Lucy Side; Dr Lisa Walker); South West Thames Regional Genetics Service, London (Prof Shirley Hodgson); NE Thames Regional Genetics Service. London (Dr. Alison Male); Birmingham Women's Hospital, Edgbaston (Professor Cyril Chapman, Dr Trevor Cole, Lucy Burgess); Sheffield Children's Hospital, Sheffield (Dr Jackie Cook), Strangeways Research Laboratory, Cambridge (Mrs Margaret Cook); Yorkhill Hospitals (Dr Rosemarie Davidson, Cathy Watt, Mark Longmuir); St Michael's Hospital, Bristol (Dr Alan Donaldson); Institute of Human Genetics (Dr Fiona Douglas, Irene Jobson); Yorkshire Regional Genetic Service (Dr Eamonn Sheridan, Julie Miller); The Wellcome Trust Sangar Institute (Professor Mike Stratton); USA: University of Utah (Professor Saundra Buys, Dr David Goldgar, Tom Conner; Vikki Venne; Dr Robert Stephenson; Dr Christopher Dechet), Abramson Cancer Centre, Philadelphia (Dr Susan Domchek, Dan Mirau), M. D. Anderson Cancer Center, Houston (Professor Sara Strom, Dr Banu Arun, Assistant Prof John W. Davis), Center for Medical Genetics, NorthShore University HealthSystem,
Evanston (Prof Wendy Rubinstein, Daniel Shevrin, Karen Kaul, Charles Brendler, Scott Weissman, Anna Newlin, Kristen Vogel, Suzanne O'Neill.)

\section{THE EMBRACE COLLABORATING CENTRES, UNITED KINGDOM AND EIRE}

Coordinating Centre, Cambridge (Prof Douglas Easton, Dr Susan Peock; Mrs Margaret Cook); North of Scotland Regional Genetics Service, Aberdeen (Prof Neva Haites: Dr Helen Gregory); Northern Ireland Regional Genetics Service, Belfast (Prof Patrick Morrison); West Midlands Regional Clinical Genetics Service, Birmingham (Dr Trevor Cole; Dr Carole McKeown); South West Regional Genetics Service, Bristol (Dr Alan Donaldson); East Anglian Regional Genetics Service, Cambridge (Dr Joan Paterson); Medical Genetics Services for Wales, Cardiff (Dr Alexandra Murray; Dr Mark Rogers; Dr Emma McCann); Dublin and National Centre for Medical Genetics, Dublin (Dr John Kennedy; Prof Peter Daly; Dr David Barton); St. James's Hospital, South East of Scotland Regional Genetics Service, Edinburgh (Dr Mary Porteous; Prof Michael Steel); Peninsula Clinical Genetics Service, Exeter (Dr Carole Brewer; Dr Julia Rankin) West of Scotland Regional Genetics Service, Glasgow (Dr Rosemarie Davidson; Dr Victoria Murday); South East Thames Regional Genetics Service, Guys Hospital London (Dr Louise Izatt; Dr Gabriella Pichert); North West Thames Regional Genetics Service, Harrow (Dr Huw Dorkins); Leicestershire Clinical Genetics Service, Leicester (Dr Julian Barwell); Yorkshire Regional Genetics Service, Leeds (Prof Timothy Bishop; Dr Carol Chu); Merseyside and Cheshire Clinical Genetics Service, Liverpool (Dr Ian Ellis); Manchester Regional Genetics Service, Manchester (Prof Gareth Evans, Dr Fiona Lalloo; Mr Andrew Shenton); North East Thames Regional Genetics Service, NE Thames (Dr Alison Male; Dr Anne Robinson); Nottingham Centre for Medical Genetics, Nottingham (Dr Carol Gardiner); Northern Clinical Genetics Service, Newcastle (Dr Fiona Douglas; Prof John Burn); Oxford Regional Genetics Service, Oxford (Dr Lucy Side; Dr Lisa Walker; Ms Sarah Durell); Department of Cancer Genetics, Royal Marsden Hospital (Dr Ros Eeles, Dr Susan Shanley, Prof Naz Rahman, Prof Richard Houlston); North Trent Clinical Genetics Service, Sheffield (Dr Jackie Cook; Dr Oliver Quarrell); South West Thames Regional Genetics Service, London (Prof Shirley Hodgson); Wessex Clinical Genetics Service, Southampton (Prof Diana Eccles; Dr Anneke Lucassen)

\section{TRIAL REGISTRATION}

IMPACT study MREC number: 05/MRE07/25.

EMBRACE study MREC number 98/5/027.

UKGPS MREC number 06/MRE02/4.

\section{REFERENCES}

[1] BCLC. Cancer risks in BRCA2 mutation carriers. J Natl Cancer Inst 1999; 91(15):1310-6.

[2] Edwards SM, Kote-Jarai Z, Meitz J, et al. Two percent of men with early-onset prostate cancer harbor germline mutations in the BRCA2 gene. Am J Hum Genet 2003; 72(1): 1-12.

[3] Tryggvadottir L, Vidarsdottir L, Thorgeirsson T, et al. Prostate cancer progression and survival in BRCA2 mutation carriers. J Natl Cancer Inst 2007; 99(12): 929-35. 
[4] Mitra A, Fisher C, Foster CS, et al. Prostate cancer in male BRCA1 and BRCA2 mutation carriers has a more aggressive phenotype. $\mathrm{Br}$ J Cancer 2008; 98(2): 502-7.

[5] Crook T, Crossland S, Crompton MR, Osin P, Gusterson BA. p53 mutations in BRCA1-associated familial breast cancer. Lancet 1997; 350(9078): 638-9.

[6] Lakhani SR, Van De Vijver MJ, Jacquemier J, et al. The pathology of familial breast cancer: predictive value of immunohistochemical markers estrogen receptor, progesterone receptor, HER-2, and p53 in patients with mutations in BRCA1 and BRCA2. J Clin Oncol 2002; 20(9): 2310-8.

[7] Scully R, Chen J, Ochs RL, et al. Dynamic changes of BRCA1 subnuclear location and phosphorylation state are initiated by DNA damage. Cell 1997; 90(3): 425-35.

[8] Bhattacharyya A, Ear US, Koller BH, Weichselbaum RR, Bishop DK. The breast cancer susceptibility gene BRCA1 is required for subnuclear assembly of Rad51 and survival following treatment with the DNA cross-linking agent cisplatin. J Biol Chem 2000; 275(31): 23899-903.

[9] Hakem R, de la Pompa JL, Sirard C, et al. The tumor suppressor gene Brcal is required for embryonic cellular proliferation in the mouse. Cell 1996; 85(7): 1009-23.

[10] Ludwig T, Chapman DL, Papaioannou VE, Efstratiadis A. Targeted mutations of breast cancer susceptibility gene homologs in mice: lethal phenotypes of Brca1, Brca2, Brca1/Brca2, Brca1/p53, and Brca2/p53 nullizygous embryos. Gene Dev 1997; 11(10): 1226-41.

[11] Phillips KA, Nichol K, Ozcelik H, et al. Frequency of p53 mutations in breast carcinomas from Ashkenazi Jewish carriers of BRCA1 mutations. J Natl Cancer Inst 1999; 91(5): 469-73.

[12] Visakorpi T, Kallioniemi OP, Heikkinen A, Koivula T, Isola J. Small subgroup of aggressive, highly proliferative prostatic carcinomas defined by p53 accumulation. J Natl Cancer Inst 1992; 84(11): 883-7.

[13] Bookstein R, MacGrogan D, Hilsenbeck SG, Sharkey F, Allred DC. p53 is mutated in a subset of advanced-stage prostate cancers. Cancer Res 1993; 53(14): 3369-73.

[14] Henke RP, Kruger E, Ayhan N, Hubner D, Hammerer P, Huland H. Immunohistochemical detection of p53 protein in human prostatic cancer. J Urol 1994; 152(4): 1297-301.

[15] Aprikian AG, Sarkis AS, Fair WR, Zhang ZF, Fuks Z, CordonCardo C. Immunohistochemical determination of p53 protein nuclear accumulation in prostatic adenocarcinoma. J Urol 1994; 151(5): 1276-80.

[16] Kallakury BV, Figge J, Ross JS, Fisher HA, Figge HL, Jennings TA. Association of p53 immunoreactivity with high gleason tumor grade in prostatic adenocarcinoma. Hum Pathol 1994; 25(1): 92-7.

[17] Shurbaji MS, Kalbfleisch JH, Thurmond TS. Immunohistochemical detection of p53 protein as a prognostic indicator in prostate cancer. Hum Pathol 1995; 26(1): 106-9.

[18] Eastham JA, Stapleton AM, Gousse AE, et al. Association of p53 mutations with metastatic prostate cancer. Clin Cancer Res 1995; 1(10): 1111-8
[19] Navone NM, Troncoso P, Pisters LL, et al. p53 protein accumulation and gene mutation in the progression of human prostate carcinoma. J Natl Cancer Inst 1993; 85(20): 1657-69.

[20] Kudahetti SGF, Ambroisine L, Foster C, et al. Immunochemistry for p53 is an independent prognostic marker for outcome in clinically localized, conservatively treated prostate cancer. BJU Int 2008 [Epub ahead of print].

[21] Jhavar S, Corbishley CM, Dearnaley D, et al. Construction of tissue microarrays from prostate needle biopsy specimens. Br J Cancer 2005; 93(4): 478-82.

[22] Remmele W, Stegner HE. Recommendation for uniform definition of an immunoreactive score (IRS) for immunohistochemical estrogen receptor detection (ER-ICA) in breast cancer tissue. Pathologe 1987; 8(3): 138-40.

[23] Grignon DJ, Caplan R, Sarkar FH, et al. p53 status and prognosis of locally advanced prostatic adenocarcinoma: a study based on RTOG 8610. J Natl Cancer Inst 1997; 89(2): 158-65.

[24] Stattin P, Damber JE, Modig H, Bergh A. Pretreatment p53 immunoreactivity does not infer radioresistance in prostate cancer patients. Int J Radiat Oncol Biol Phys 1996; 35(5): 885-9.

[25] Stattin P, Bergh A, Karlberg L, Nordgren H, Damber JE. p53 immunoreactivity as prognostic marker for cancer-specific survival in prostate cancer. Eur Urol 1996; 30(1): 65-72.

[26] Quinn DI, Henshall SM, Head DR, et al. Prognostic significance of p53 nuclear accumulation in localized prostate cancer treated with radical prostatectomy. Cancer Res 2000; 60(6): 1585-94.

[27] Rodrigues NR, Rowan A, Smith ME, et al. p53 mutations in colorectal cancer. Proc Natl Acad Sci USA 1990; 87(19): 7555-9.

[28] Davidoff AM, Herndon JE, 2nd, Glover NS, et al. Relation between p53 overexpression and established prognostic factors in breast cancer. Surgery 1991; 110(2): 259-64.

[29] Carter BS, Ewing CM, Ward WS, et al. Allelic loss of chromosomes $16 \mathrm{q}$ and $10 \mathrm{q}$ in human prostate cancer. Proc Natl Acad Sci USA 1990; 87(22): 8751-5.

[30] Sarkis AS, Dalbagni G, Cordon-Cardo C, et al. Nuclear overexpression of p53 protein in transitional cell bladder carcinoma: a marker for disease progression. J Natl Cancer Inst 1993; 85(1): 539.

[31] Visscher DW, Sarkar FH, Shimoyama RK, Crissman JD. Correlation between p53 immunostaining patterns and gene sequence mutations in breast carcinoma. Diagn Mol Pathol 1996; 5(3): 187-93.

[32] D'Amico AV, Moul J, Carroll PR, Sun L, Lubeck D, Chen MH. Prostate specific antigen doubling time as a surrogate end point for prostate cancer specific mortality following radical prostatectomy or radiation therapy. J Urol 2004; 172(5 Pt 2): S42-6, discussion S6-7.

[33] Antoniou AC, Cunningham AP, Peto J, et al. The BOADICEA model of genetic susceptibility to breast and ovarian cancers: updates and extensions. Br J Cancer 2008; 98(8): 1457-66. 